\title{
Socioeconomic constraints, environmental impacts and drivers of change in the Congo Basin as perceived by logging companies
}

\author{
MANUEL RUIZ PÉREZ ${ }^{1 *}$, DRISS EZZINE DE BLAS ${ }^{1}$, ROBERT NASI ${ }^{2}$, JEFFREY A. SAYER ${ }^{3}$, \\ ALAIN KARSENTY ${ }^{2}$, MARIEKE SASSEN ${ }^{2}$, CLAUDINE ANGOUÉ ${ }^{4}$, NORBERT GAMI ${ }^{5}$, \\ OUSSEYNOU NDOYE ${ }^{6}$, GRÉGOIRE NGONO ${ }^{7}$, JEAN-CLAUDE NGUINGUIRI ${ }^{8}$, \\ DONATIEN NZALA ${ }^{9}$, BENJAMIN TOIRAMBE ${ }^{10}$ AND YVES YALIBANDA ${ }^{11}$ \\ ${ }^{1}$ Dpt Ecologia, Edificio Biología, Calle Darmin 2, Universidad Autónoma de Madrid, 28049 Madrid, Spain, ${ }^{2}$ CIRAD/CIFOR, Campus \\ International de Baillarguet, TA 10/D, 34398 Montpellier Cedex 05, France, ${ }^{3}$ WWF International, Avenue du Mont Blanc, 1196 Gland, \\ Switzerland, ${ }^{4}$ UOB Département de Sociologie, BP 17055, Libreville, Gabon, ${ }^{5} 100$ rue Lampama, Talangaï, Brazzaville, Congo, ${ }^{6}$ CIFOR \\ Central and West Africa Regional Office, BP 2008, Messa, Yaoundé, Cameroon, ${ }^{7}$ Institut de Recherches Agronomiques pour le Développement \\ (IRAD), BP 2163, Yaoundé, Cameroon, ${ }^{8}$ ITTO, PO Box 329, Libreville, Gabon, ${ }^{9}$ Université Marien Ngouabi/IDR, BP 13647, Brazzaville, \\ Congo, ${ }^{10}$ Laboratoire de foresterie tropicale et subtropicale, FUSAGx, B-5030 Gembloux, Belgium, and ${ }^{11}$ Ministère des Eaux, Forêts, Chasses, \\ Pêches, de l'Environnement et du Tourisme, BP 830, Bangui, Central African Republic
}

Date submitted: 2 August 2005 Date accepted: 26 July 2006 First published online: 12 October 2006

\section{SUMMARY}

The external factors that influence the environmental, social and economic performance of logging companies were studied using a questionnaire submitted to 30 logging concessions in five countries of the Congo Basin. This paper analyses socioeconomic constraints and environmental impacts experienced by these concessions, as well as their response to major external drivers of change. Concessionaires considered investment and operating finance their main constraint, followed by insufficient technical and human capacities, and inconsistent application of official regulations. Environmental problems directly produced by concessions' operations represented around one-third of the total score for environmental problems reported. Damage caused by construction of logging roads and erosion were identified as the main issues. Induced problems (two-thirds of the total score) were dominated by hunting, with encroachment and illegal logging perceived as much less significant. Policies, infrastructure, markets and technology are key external drivers of change in concessions' practices, while regional and international forestry institutions reportedly have the least influence, reflecting an emerging scepticism about the proliferation of international institutions and initiatives promoting sustainable forestry.

Keymords: Congo Basin, drivers of change, environmental impacts, industrial logging, socioeconomic constraints

\section{INTRODUCTION}

The Congo Basin is home to the second largest area of tropical rainforest in the world. The forests of the region

*Correspondence: Dr Manuel Ruiz Pérez Tel: +34 914978000 Fax: +34914978001 e-mail: manuel.ruiz@uam.es are very important because of their global biodiversity value, as the resource base for major export-oriented industries, and for the wide variety of products and services they provide to local communities. As early as 1912, during the German colonization period in Cameroon, those values were recognized through the adoption of legal prescriptions for granting of logging permits only to non-abusive forestry concerns (Hédin 1930).

At independence there were only a few scattered industrial logging operations in the region, mainly near the coast. However during the post-colonial period, log exports became significant contributors to the economies of all of the countries. The last two decades have seen rapid expansion of industrial logging and concessions have now been allocated throughout the more accessible forests of all countries. Only a few remote areas in the heart of Gabon and the Democratic Republic of Congo (DRC) are free of major logging activities (Minnemeyer 2002). Over the past decade, the operating environment for logging companies (and other industrial sectors) has become more difficult. Economies are stagnant or declining, institutions and infrastructure are weak, armed conflict has destabilized several countries and corruption has become rampant (Baker et al. 2003; Muna 2004). Illegal forestry operations have become such a problem that they are the subject of international conferences (Kabemba 2003). In some locations, like East and Central Cameroon, established companies suffer increasing competition from an explosion of illegal activity (Fabing \& Bakouma 2002; Djire 2004).

A number of conservation priority setting exercises have recognized the forests as having global environmental values, mainly for their unique biodiversity (Mittermeier et al. 1999). The forests of the region are now the object of a major international conservation initiative (Congo Basin Forest Partnership launched at the World Summit on Environment and Sustainable Development in Johannesburg in 2002 (USAID [US Agency for International Development] 2006).

Despite this, industrial logging remains a major economic activity in Congo Basin countries. It is normally highly selective, extracting less than two trees per hectare, (FAO 
[Food and Agriculture Organization of the United Nations] 2003) although areas close to ports have generally been more intensively logged. As elsewhere in the tropics (Pearce et al. 2003), logging is controversial and hotly debated, especially by conservation and development nongovernmental organizations (NGOs) and industrial lobbies. These interest groups are taking contrasting and diverse positions. Some NGOs have engaged in a 'stick and carrot' approach, trying to promote sustainable forest management through certification, demonstration projects and general technical support (for example the WWF [Worldwide Fund for Nature], WRI [World Resources Institute]-Global Forest Watch). While remaining generally critical of logging practices in the region, they believe that promoting sustainable forestry is more likely to lead to better environmental and social outcomes than simply opposing all logging. At the same time, some media and NGOs have remained highly critical of the corruption associated with logging and have portrayed any logging activity as inevitably damaging to the environment and to the livelihoods of local people (for example WRM [World Rainforest Movement] 2002; Greenpeace Switzerland 2004), and some authors have portrayed logging as an integral part of a dysfunctional society (Labrousse \& Verschave 2003).

Logging has occurred in areas of armed conflict, being both the cause and the effect of these conflicts. The term 'conflict timber' has been coined to describe timber that has been exploited to fund wars (Klare 2002; Verbelen 2003; Thomson \& Kanaan 2004). The bushmeat trade is portrayed as a major environmental concern (Robinson \& Bennett 2000; Brown \& Williams 2003), commonly triggered or facilitated by logging infrastructures. These issues have helped create an overall negative perception of the logging industry in the region that tends to consider it as an internally homogeneous sector, uniformly unsustainable, closely linked to corrupt political elites and possessing insufficient incentives to apply modern concepts of sustainable forest management (Labrousse \& Verschave 2003; Vandenhaute \& Heuse 2006).

Yet field experience shows that there is a great deal of variability in the way logging companies operate (Debroux \& Karsenty 1997; Guilguy 1997; Karsenty \& Pierre 2005; Ruiz Pérez et al. 2005). A number of logging concessions are close to (Tansformation Reef Cameroon), or have recently achieved (Congolaise Industrielle des Bois, Wijma) certification by the Forest Stewardship Council (FSC), as meeting its strict criteria for sustainable forest management (WWF Central African Regional Programme Office 2005; Forest Peoples Programme 2006; FSC 2006). The overall objective of this study was to investigate how this variability of logging conditions relates to variability of socioeconomic constraints and environmental problems as perceived by the loggers themselves, and to determine what forces a diverse logging industry to change their practices. We focused our study on the five ITTO (International Tropical Timber Organization) member countries of the region, namely Cameroon, CAR (Central African Republic), Congo, DRC and Gabon.

\section{METHODS}

A questionnaire survey was designed around two sets of questions. The first related to the perception of socioeconomic and environmental problems caused by logging operations in the concession and the surrounding area. The second investigated the assessment of concessionaires of the main 'drivers of change', the external factors causing them to alter their plans and practices. The questions have been used to assess variations in concessionaires' perceptions of problems according to concession categories.

The questionnaire consisted of nine socioeconomic and seven environmental factors. Most socioeconomic factors were split into sub-headings that were later averaged to give a factor's mean value. In addition, the questionnaire sought the views of the logging companies on 12 potential drivers of change. Responses were scored on a scale of 1 to 5 ; factors that were not considered relevant by interviewees were given a score of 0 .

Concessions were grouped by size: small $(<5000 \mathrm{ha})$, which is the usual limit for community and artisanal concessions in the region; medium (5000-100000 ha); large (100000$250000 \mathrm{ha})$ and very large (> $250000 \mathrm{ha})$. We distinguished companies financed internationally from those with national capital. Lastly, we classified companies according to whether their main markets were within the region, in Europe or in Asia.

In order to standardize the questionnaire's implementation and subsequent analysis, three regional meetings were organized: a first meeting to define and interpret the questions and the way in which they were going to be posed to the concessionaires; an intermediate meeting to check questionnaire progress and data validation; and a final meeting devoted to the analysis and common interpretation of results.

The questionnaire was administered to senior concession managers through personal interviews. We applied the questionnaire to a stratified sample of 30 concessions selected on the basis of their willingness to cooperate and quality of the information they could provide. We included 5-7 concessions per country and attempted to include concessions from different categories of legal status and ownership (Table 1).

The analysis of problems and drivers of change at the most aggregated level was based on mean values calculated from the scores given by respondents. The analysis of detailed factors within each of the above main dimensions was based on raw data, except when the factor was split in sub-headings, in which case we used mean sub-heading values for the factor. Non-parametric tests for more than two independent samples (Kruskal-Wallis $\chi^{2}$ ), appropriate for ordinal data, more robust to outliers and not requiring normal distribution, were conducted to assess differences (at $p>0.10$ ) between countries and concession categories. Cluster analysis (distance similarity index and UPGMA [Unweighted Pair Group Method with Arithmetic mean]) was used to analyse the association between different drivers of change. 
Table 1 Distribution of the sample by main category.

\begin{tabular}{llc}
\hline \hline Category & & Sample size \\
\hline Country & Cameroon & 7 \\
& Central African Republic & 5 \\
& Congo & 7 \\
& Democratic Republic of Congo & 5 \\
\multirow{5}{*}{ Origin of capital } & 6 \\
& Gabon & 10 \\
Size & National & 20 \\
& Foreign & 4 \\
& Small & 6 \\
& Medium & 10 \\
Market & Large & 10 \\
& Very large & 7 \\
& Local - national & 18 \\
& European & 5 \\
\hline \hline
\end{tabular}

Table 2 Decreasing relevance of socioeconomic problems: mean and median scores.

\begin{tabular}{lll}
\hline \hline Problems & Mean & Median \\
\hline Funding & 3.2 & 4 \\
Capacity & 2.5 & 3 \\
Rule implementation & 2.5 & 3 \\
Macroeconomics & 2.4 & 2 \\
Pressure groups & 2.3 & 2 \\
Social context & 2.2 & 2 \\
Demand & 2.1 & 2 \\
Legal framework & 1.9 & 1 \\
Granting procedures & 1.9 & 1 \\
\hline \hline
\end{tabular}

Given the large variation among countries in the number of officially recorded logging concessions, our sample did not provide the same intensity of sampling per country. Moreover, some categories like small size (frequently community operated) concessions did not occur in all countries. This, together with the relatively small size of the sample which precludes cross tabulation and controls for possible effects of different categories, was a limitation of the study.

\section{RESULTS}

\section{Perception of socioeconomic constraints by concessionaires}

Mean scores for the nine groups of constraints (Table 2) showed a smooth increase from those perceived as the least important (concession granting procedures and legal frameworks, mean scores of 1.9) to those perceived as more significant (implementation of rules and technical and human capacities, mean scores of 2.5). Finance-related constraints scored highest, with a mean of 3.2 .

Concessions showed variations in the assessment of socioeconomic constraints by country (Kruskal-Wallis $\left.\chi^{2}=15.339 ; d f=4 ; p=0.004\right)$. The DRC was perceived as the most problematic country. Cameroon received the second highest score and showed the largest in-country variation,
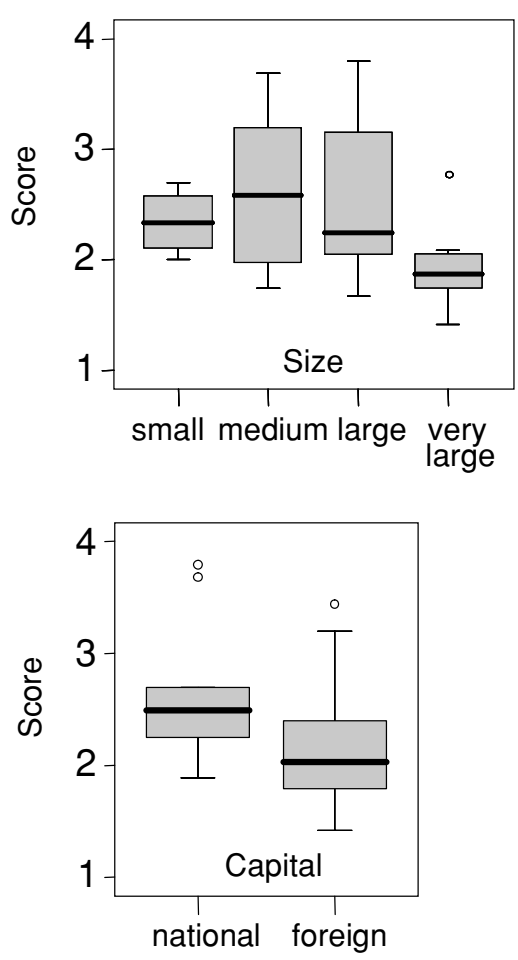

Figure 1 Interquartile distribution box-plot for socioeconomic problems by size of concession and origin of capital. The rectangle indicates the interquartile range ( $25 \%$ and $75 \%$ of cases), the thick line crossing it indicates the median; small circles represent outliers (between 1.5 and 3 times the box length).

illustrating the larger diversity of concession types included in the sample. These ranged from well-established and well-connected large-scale industrial operations to recently established small community concessions. The scores in the other three countries were similar and lower than those of $\mathrm{DRC}$ and Cameroon.

We expected that different types of concessions would experience different constraints and would have different perceptions of key problems. In particular, we tested the effect of concession size and origin of capital in the rating of constraints (Fig. 1). The box-plot indicates that intermediate size concessions tended to score higher than small and very large concessions, medium and large sized concessions tending to give higher scores, however the differences were not significant $\left(\chi^{2}=5.718 ; d f=3 ; p=0.126\right)$.

Differences in the rating of constraints (Fig. 2) were significant for finance (particularly affecting small concessions) $\left(\chi^{2}=9.485 ; d f=3 ; p=0.023\right)$, macroeconomic context (middle size concessions) $\left(\chi^{2}=7.315 ; d f=3\right.$; $p=0.063$ ) and action of pressure groups (middle size and small concessions) $\left(\chi^{2}=8.501 ; d f=3 ; p=0.037\right)$.

Likewise, differences in the rating of socioeconomic constraints according to origin of capital were statistically significant $\left(\chi^{2}=5.263 ; d f=1 ; p=0.022\right.$; Fig. 1$)$ the scores being highest for national concessions. There were major 

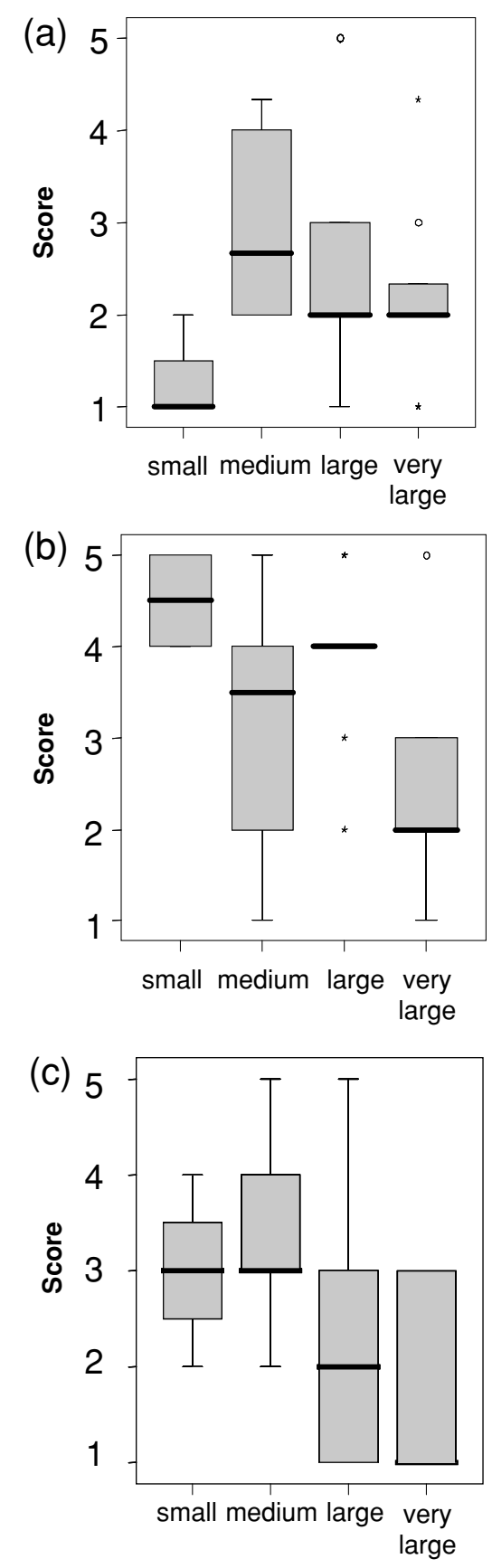

Figure 2 Interquartile distribution box-plot of statistically significant problems by concession size: $(a)$ macroeconomics, (b) funding and (c) pressure groups. Small circles represent outliers (between 1.5 and 3 times the box length); asterisks represent extreme values (more than 3 times the box length).

differences in perceptions of individual constraints, these being significant for finance $\left(\chi^{2}=6.354 ; d f=1 ; p=0.012\right)$, market demand $\left(\chi^{2}=7.028 ; d f=1 ; p=0.008\right)$ and technical and human capacities $\left(\chi^{2}=4.442 ; d f=1 ; p=0.035\right)$. Alternatively, although not statistically significant, foreignowned concessions tended to experience more problems than national concessions in adjusting to legal requirements.
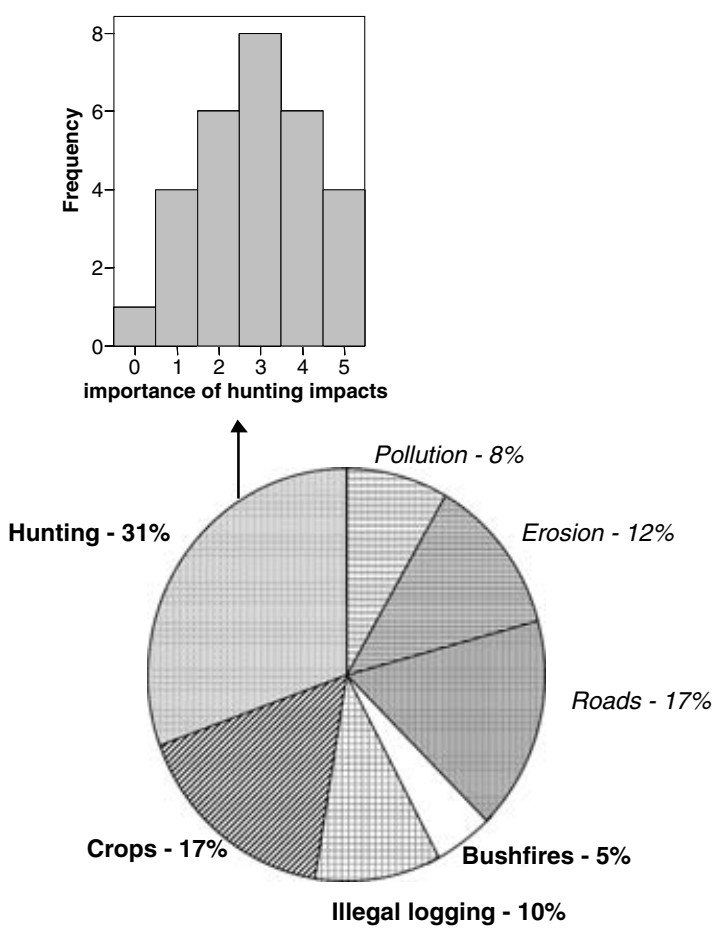

Figure 3 Perception of environmental impacts by concessionaires. The percentage represents the contribution of the scores of that particular impact to the total sum of scores for all impacts. Endogenous problems are labelled in italics. The histogram shows the distribution of scores for hunting.

\section{Perception of environmental problems by concessionaires}

Environmental impacts represented as the percentage contribution of the scores for that particular impact to the sum of scores for all impacts helped us to discern two basic types of environmental problems: those endogenous to the concession, caused by actual logging practices, and those where the concession was a 'facilitator' but not a direct cause. The first group includes three issues, in increasing order of importance: pollution, erosion and damage caused by logging roads (Fig. 3). Together they accounted for $37 \%$ of total scores of all problems identified.

Concessionaires recognized that their presence led to problems that were outside their immediate control. They ranked increasing frequency of bush fires as a very minor problem, but acknowledged progressively increasing impacts of illegal logging, encroachment and hunting in areas where logging infrastructure facilitated illegal access. The term 'encroachment' denotes farmers taking advantage of logging roads to move into concession areas in violation of the law and of concessionaire's plans. We differentiated this from the exercise of the rights of local populations that felt that the concession had taken over their traditional lands. Together illegal logging, encroachment and hunting contributed $63 \%$ of the total scores for all perceived problems. It is noteworthy 
Table 3 Decreasing relevance of drivers of change: mean and median scores. ITTO = International Tropical Timber Organisation, $\mathrm{OAB}=$ Organisation Africaine du Bois, CEFDHAC $=$ Conférence sur les Ecosystèmes de Forêts Denses et Humides d'Afrique Centrale, COMIFAC $=$ Conférence des Ministres de Forêts de l'Afrique Centrale.

\begin{tabular}{lll}
\hline \hline Driver of change & Mean & Median \\
\hline New policies & 3.6 & 4 \\
Infrastructures & 3.1 & 3 \\
Markets & 2.4 & 2 \\
Technological changes & 2.4 & 2 \\
Certification & 2.2 & 2 \\
Continental competition & 2.2 & 2 \\
Pressure groups & 2.1 & 2 \\
Regional competition & 1.8 & 1 \\
ITTO & 1.7 & 1 \\
OAB & 1.5 & 1 \\
CEFDHAC & 1.3 & 1 \\
COMIFAC & 1.2 & 1 \\
\hline \hline
\end{tabular}

that most respondents considered hunting a major problem (Fig. 3). All but one of the respondents mentioned it, and it was seen as particularly serious in Cameroon.

There are clear differences between nationally and foreign owned concessions. National and foreign owned concessions gave similar environmental problem scores (2.64 and 2.69, respectively). However, the importance they gave to 'endogenous' and 'induced' problems differed $\left(\chi^{2}=4.636 ; d f=1 ; p=0.031\right.$ for endogenous, $\chi^{2}=4.359$; $d f=1 ; p=0.037$ for induced). Nationally owned concessions tend to assign almost three times as much importance to induced impacts as to endogenous ones. Conversely, foreign owned concessions saw endogenous impacts, directly created by the concession, as more important than those created by external agents induced by their presence.

\section{Drivers influencing changes in concessionaire behaviour}

New policies, changes in infrastructure, markets and technology were the main drivers of changes in the logging industry of the region (Table 3). At the other extreme, regional and international forest-related institutions were considered to have the least direct influence. Competition with other countries in the region and with logs from South America and South-east Asia were seen as only having moderate influence on concession activities. Institutional relations, pressure groups and certification were also only seen as having a moderate influence in promoting change.

Scores for the importance of drivers of change varied among countries $\left(\chi^{2}=10.552 ; d f=4 ; p=0.032\right)$. The DRC had the highest scores, followed by the Republic of Congo and Cameroon with intermediate scores, and Gabon and the CAR with the lowest scores. Countries also showed significant differences in the importance given to competition within
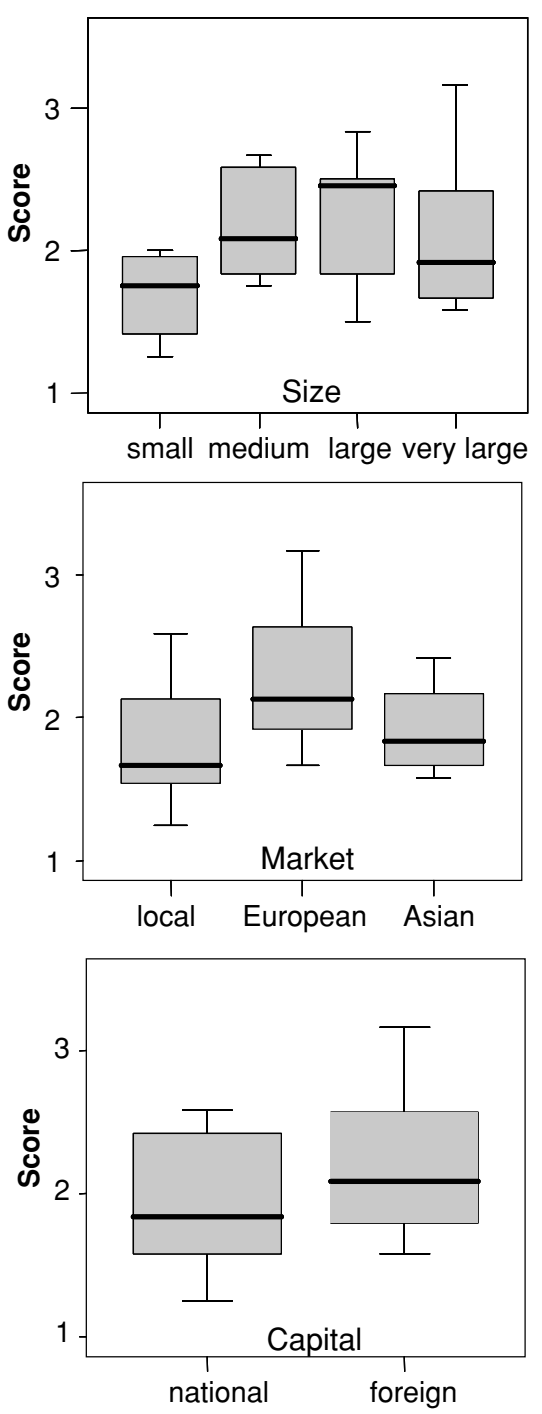

Figure 4 Interquartile distribution box-plot of drivers of change by size, market orientation and capital.

the region $\left(\chi^{2}=10.938 ; d f=4 ; p=0.027\right)$ and competition with South America and South-east Asia $\left(\chi^{2}=8.000 ; d f=4\right.$; $p=0.092)$. There were also significant differences in perceptions of the role of technological change $\left(\chi^{2}=10.642 ; d f=4\right.$; $p=0.031)$, new policies $\left(\chi^{2}=10.556 ; d f=4 ; p=0.032\right)$ and the Conférence sur les Ecosystèmes de Forêts Denses et Humides d'Afrique Centrale (CEFDHAC), a civil society forum convened by the World Conservation Union (IUCN) $\left(\chi^{2}=10.560 ; d f=4 ; p=0.032\right)$ amongst the countries. Cameroon scored highest for the impact of CEFDHAC.

We expected that the importance of drivers of change would differ amongst the types of concession, and investigated effects of size, markets and origin of capital on the rating of these drivers. Although not statistically significant, scores for the importance of drivers of change tended to be highest in medium to large concessions (Fig. 4). Medium to large concessions also scored highest for socioeconomic constraints, and stood out in their strong differentiation of technology 
$\left(\chi^{2}=10.592 ; d f=3 ; p=0.014\right)$. Although all types of concessions considered infrastructure as a main factor determining change, medium and large concessions rated it significantly higher than small and very large concessions $\left(\chi^{2}=7.599 ; \quad d f=3 ; \quad p=0.055\right)$. They operate in an intermediate scale between small concessions generally located near inhabited places and depending totally on public infrastructure, and the very large concessions that operate in remote areas and usually construct their own infrastructure.

Market orientation was the only factor significantly differentiating the scores of drivers of change $\left(\chi^{2}=5.433\right.$; $d f=2 ; p=0.066)$. Concessions supplying the European market rated the influence of drivers of change significantly higher than those supplying Asian or domestic markets (Fig. 4). Such scoring difference was particularly strong for competition with South America and South-east Asia, with higher scores for concessions supplying the European market $\left(\chi^{2}=9.016 ; d f=2 ; p=0.011\right)$. ITTO as a driver of change was also significantly more important for concessions supplying the European market $\left(\chi^{2}=5.748\right.$; $d f=2 ; p=0.056)$.

Although the difference was not significant, companies supported by international capital tended to score higher than national entities. Competition with South America and South-east Asia $\left(\chi^{2}=14.530 ; d f=1 ; p=0.000\right)$ and ITTO $\left(\chi^{2}=3.485 ; d f=1 ; p=0.062\right)$ differentiated these groups, with foreign companies giving higher scores for both (Fig. 4).

Cluster analysis indicated a close association between the five regional and international institutions with a forest mandate (ITTO; African Timber Organization [ATO]; Conférence des Ministres de Forêts de l'Afrique Centrale [COMIFAC]; and CEFDHAC) all of which were perceived as related and scoring low as drivers of change (Fig. 5). Certification was associated with pressure groups. The influence of markets tended to be associated with intra-regional and inter-continental competition, while technological change seemed to be loosely related to infrastructure. New policies, the driver with the highest score, formed an outlier, indicating its special relevance.

\section{DISCUSSION}

A number of patterns and statistically significant trends emerge from the data, suggesting that the basic approach was sound and that results reflected the great range of variability that exists within the industrial logging sector in Central Africa.

Our analyses illustrate a number of specific issues related to country and type of concession. The concessionaires identified lack of finance as the main socioeconomic constraint they were experiencing. Small concessionaires' answers highlighted the lack of investment and weak cash-flow as major constraints. Larger companies reported being more hampered by taxation, corruption costs. Lack of technical and human capacities and inconsistent application of official regulations and rules were seen as slightly less serious problems.

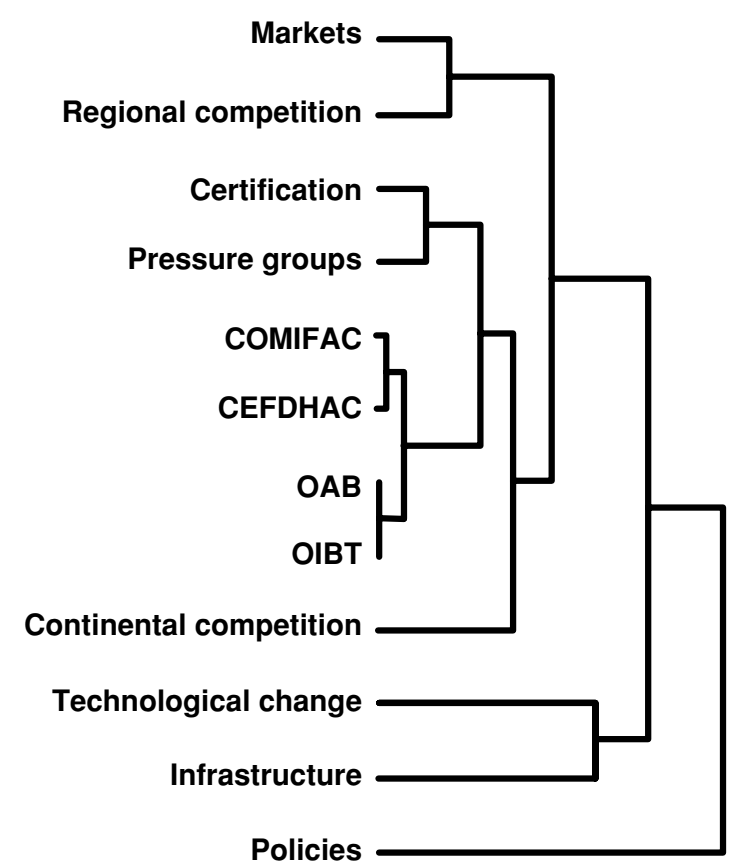

Figure 5 Unweighted pair group method with arithmetic mean (UPGMA) cluster groups of drivers of change.

OIBT $=$ Organisation Internationale des Bois Tropicaux (Also known as ITTO), $\mathrm{OAB}=$ Organisation Africaine du Bois, CEFDHAC $=$ Conférence sur les Ecosystèmes de Forêts Denses et Humides d'Afrique Centrale, COMIFAC $=$ Conférence des Ministres de Forêts de l'Afrique Centrale.

The significantly higher scores for constraints in the DRC are consistent with the prevailing precarious situation in that country (International Crisis Group 2005). Logging activities were just resuming after a decade of civil strife, infrastructure was deficient or non-existent, administration was inefficient, and the sector was being restructured. There has been strong World Bank pressure for new regulations to facilitate the sustainable expansion of industrial logging (Kuediasala 2005). Cameroon contrasted strongly with the situation in the DRC. The regulatory framework was comprehensive, a permanent forest estate had been demarcated and concessions were allocated on the basis of public auctions. There was a ban on the export of logs for some important species. The requirement that $\operatorname{logs}$ be processed locally was creating a problem of industrial over-capacity for a shrinking resource base.

The results suggest that sensitivity to socioeconomic constraints was affected by size of concession. In general, concessions in our very large and small categories rated socioeconomic constraints lowest, whereas those in our medium and large categories had the highest scores. Very large concessions seem to have the influence and resources to control their operating environment. Their size and influence sheltered them from most problems. Small concessions, often community or family based, focused on local buyers and were protected against external forces by the fact that they were well integrated into local society. 
Medium and large concessions were trapped between these two extremes. They were too small to have significant influence over their local operating environment but were large enough to have to compete in the international arena and to be exposed to external pressures. They were therefore the ones that experienced the largest number of problems, and also the ones that experienced the highest variation in conditions, as reflected by the length of the interquartile distribution graph.

Endogenous environmental problems amounted to $37 \%$ of the total score for environmental problems identified by the concessionaires, with logging roads and erosion being the main issues. Induced problems (63\% of the total score) were dominated by hunting, followed at a large distance by agricultural encroachment and illegal logging. The main point upon which the loggers and their critics agreed was the major impact of hunting. This is consistent with international research (Robinson \& Bennett 2000; Brown \& Williams 2003). It is interesting to compare the perceptions of logging operators with the image presented by some media and conservation NGOs. While hunting, illegal logging and roads (that facilitate hunting and illegal logging) are prominent in the international debate about logging in Central Africa (Sayer et al. 2005), fires, pollution, erosion and agricultural encroachment (the last two rated higher than illegal logging by concessionaires) were totally absent from these debates.

Our data highlighted country differences in the importance allocated to different types of environmental problems. The incipient logging industry of the DRC tended to stress induced problems, whereas mature logging industries such as those of Cameroon and Gabon tended to emphasize endogenous impacts. Likewise, foreign-owned concessions stressed the endogenous problems they caused, while nationally-owned concessions tended to attribute more importance to induced problems. It is unclear whether these differences are the result of objective variations in environmental effects or a product of the social and political discourse to which the actors were exposed. It would be interesting to pursue this analysis with a larger sample of concessions and with direct field assessments.

Some logging operators seemed to be dynamic enterprises, adapting, anticipating and promoting changes in the whole sector. Policy, infrastructure, markets and technology were the key drivers of change identified in our sample. Regional and international forestry institutions tended to be grouped in the responses and were perceived as having the least influence in changing industry practices. This reflects an emerging scepticism about the proliferation of international institutions and initiatives aimed at promoting sustainable forestry. Most of our respondents considered that more practical, on-theground factors were more significant, with the exception of certification and associated pressure groups, which were perceived as having a moderate influence on changes in the concessions. This suggests that lobbying groups who were promoting certification were succeeding in inducing changes in management practices by loggers. In the Amazon region, a Chinese wood industry had been searching for certified timber, end products of which are destined for the European market (ITTO 2005). This supports the conclusion of a global review of uptake of the Ecosystem Approach Principles adopted in 2000 by the Convention on Biological Diversity that moves towards more environmentally and socially benign forestry in many countries have been driven by local pressures and incentives much more than by international pressures and agreements (Sayer \& Maginnis 2005).

Cameroon scored highest for the impact of CEFDHAC, suggesting that although CEFDHAC is a regional structure it has more influence in the country that hosts its secretariat than it does elsewhere.

The new policies that are being developed by several countries have the highest influence in changing concession practices. An analysis of the major changes brought about by the policies that have appeared in the last decade showed that they are the direct result of two key policy components:

- Environmental regulations: high-standard management plans, following strict national guidelines and norms, have become mandatory for concessions. This has lead to a growing demand for technical expertise that is only partially being met by a handful of foreign consulting companies that charge international fees. Only large concessionaires can really afford such technical support. CAR is an exception where a public institution, backed by foreign aid, is in charge of preparing the management plans for the six large companies who operate in the country.

- Forest taxation reforms and social transfer requirements have generally increased the fiscal and financial pressures on companies. This is putting pressure on companies that have variable production or that are sensitive to timber demand and price variations on the international market.

The diversity of the responses from different countries reflects the variability of conditions within the region (Ruiz Pérez et al. 2005). The high scores in DRC are more an indication of fast changes in its logging industry after the stabilization of the political situation than a reflection of a dynamic and innovative industry. The high ranking in DRC indicates a very low starting point. Gabon and specially the CAR appeared to have the least responsive (not necessarily least advanced) logging concessions, which is probably linked to the fact that these two countries had large concessions, relatively little domestic processing and a fairly stable regulatory and institutional framework.

The higher scores given to inter-continental competition and the role of ITTO by concessions supplying the European market seems to be an indication of new developments in international tropical timber markets. Asian markets are growing faster than European markets, and ITTO is perceived as a guarantor of international market stability for European more than for Asian markets. 


\section{CONCLUSIONS}

Scale (both physical and financial), origin of capital and market orientation have been acting as structuring factors for the forest sector in the region. Concentration on one hand and fragmentation on the other seem to be the current trend in the logging industry of the Congo Basin. Large foreign-owned companies seem to be able to cope with new public regulations and export standards required by western markets; many small African companies are positioned to exploit local markets and use their ties with local administrations and national governments to avoid costly changes which would be required if laws were enforced stringently. Medium-sized and large companies are suffering the disadvantages of social visibility (Hoh \& Vignaux 2006) which makes bypassing the law much more difficult. They are also exposed to greater competition and to the environmental requirements of their main export markets. An example of this is the recent collapse of mediumsized and large companies in Cameroon and Gabon (Buttoud et al. 2005; Fochivé 2005).

Many new public policies have been prepared with the active support of foreign donors. They have the effect of increasing the fixed costs of logging activities, thus favouring the largest companies with strong financial backing. This is encouraging a trend towards the consolidation of the industry into a smaller number of large companies. The new regulatory frameworks come at a time of a major shift in global tropical timber markets. A notable example of the consolidation of the industry is the expansion of the Hong Kong-based Vicwood group, which controls six companies in Cameroon (Global Forest Watch 2005), and in three years has taken over two existing companies in Congo-Brazzaville and the CAR. Governments have tried to avoid excessive industry consolidation by imposing limits on concession size (200 000 ha in Cameroon, for example). However such measures are difficult to apply when many concessions operate under different names, but are owned by a single holding company.

'Consolidation at the top' and 'fragmentation at the bottom' are not totally new phenomena. The globalization and integration processes taking place in the forest industry have already been reported (ILO [International Labour Organization] 2001). Studies suggest that large companies prefer to obtain their raw materials from smaller enterprises. This strategy enables them to avoid regulations (notably the volume limitation imposed by the limitations on areas annually open to logging) and to escape some taxes (CIRAD [Centre International en Recherche Agronomique pour le Développement]/Institutions et Développement 2000). However, since many of these large companies are now looking for high-standard certification, it is likely that such a practice will tend to decline.

The policy discourse amongst some conservation and development organizations is driven by an over-simplified view of the factors at work in determining the performance of logging companies in the Congo Basin. There is a failure to recognize the complexity and variability of the situation on the ground and to acknowledge the opportunities that exist to encourage companies to improve their standards of corporate responsibility. Outside advisers tend to address problems through advocating further regulation and restrictions and to ignore the options for incentives and the removal of those constraints that discourage moves to better performance.

Our results support the view of the logging industry as a diversified sector. They offer evidence of the linkage between the conditions in which concessions operate and the variation in concessionaires' perceptions and attitudes and suggest explanations for that variability. A more extensive survey using this approach could provide firm conclusions on the origins of that variability and would suggest policy responses that could better target causes of poor performance.

\section{ACKNOWLEDGEMENTS}

ITTO supported the pilot study leading to this paper. We also thank the concession managers who responded to the questionnaire and helped clarify all issues raised. Two anonymous reviewers gave suggestions that improved the manuscript.

\section{References}

Baker, M., Clausen, R., Kanaan, R., N'Goma, M., Roule, T. \& Thomson, J. (2003) Conflict timber: dimensions of the problem in Africa and Asia. Volume III: African cases. Biodiversity and Sustainable Forestry Indefinite Quantity Contracts (BIOFOR/ IQC). USAID, Washington, DC, USA.

Brown, D. \& Williams, A. (2003) The case for bushmeat as a component of development policy: issues and challenges. International Forestry Reviem 5(2): 148-155.

Buttoud, G., Karsenty, A., Memvie, B., Tissari, J. \& Sollo, J.-W. (2005) Mission Technique de Diagnostic de la Gestion Durable des Forêts en vue d'atteindre l'Objectif 2000 de l'OIBT en appui au Gouvernement de la République Gabonaise. ITTO, Yokohama, Japan.

Centre International en Recherche Agronomique pour le Développement (CIRAD)/Institutions et Développement, coord. (2000) Audit économique et financier du secteur forestier au Cameroun. Rapport final. Ministry of Economy and Finances, Yaoundé, Cameroon.

Debroux, A. \& Karsenty, A. (1997) L'implantation des sociétés asiatiques en Afrique centrale : Rimbunan Hijau au Cameroun. Bois et Forêts des Tropiques 254(4): 80-85.

Djire, A. (2004) Rapport final de l'étude sur le secteur informel du bois d'oeuvre en RDC. Rapport d'appui à la Revue économique du secteur forestier. Banque Mondiale et Ministère de l'Environnement de la RDC, Kinshasa, RDC.

Fabing, A. \& Bakouma, J. (2002) Dynamique du secteur informel et des petites enterprises au sein de la filière bois dans la région sud du Congo. CIRAD, Montpellier, France: 47 pp.

FSC (2003) Forest outlook study for Africa: étude prospective du secteur forestier en Afrique. FAO, Rome, Italy.

Fochivé, E. (2005) Évolution du secteur forestier sur la période 19982003 (opérateurs économiques, investissements, emplois). Study for the World Bank, Yaoundé, Cameroon.

Forest Peoples Programme (2006) Protecting indigenous rights in the Republic of Congo through the application of FSC Standards in 
forest plans: a review of progress made by Congolaise Industrielle des Bois (CIB) against FSC Principles 2 and 3. Forest Peoples Programme, Moreton-in-Marsh, UK.

FSC (2006) FSC certificate list [www document]. URL http://www. fsc.org/en/whats_new/fsc_certificates

Global Forest Watch (2005) Interactive forestry atlas of Cameroon an overview. Ministry of Environment and Forest (MINEF) and the Global Forest Watch, World Resources Institute, Washington, DC, USA.

Greenpeace Switzerland (2004) Greenpeace Switzerland blockades import of African timber [www document]. URL http://archive. greenpeace.org/forests/africa/resources.htm

Guilguy, C. (1997) Faut-il avoir peur des investisseurs asiatiques? Marchés Tropicaux et Méditerranéens 2687: 10-15.

Hédin, L. (1930) Etude sur la forêt et les bois du Cameroun sous mandat français. Commissariat du Cameroun, Paris, France.

Hoh, A.V. \& Vignaux, B. (2006) L'Afrique n'est plus l'eldorado des entreprises françaises. Le Monde Diplomatique 623: 12-13.

ILO (2001) Globalization and sustainability: The forestry and wood industries on the move. ILO, Geneva, Switzerland.

International Crisis Group (2005) The Congo's transition is failing: crisis in the Kivus [www document]. URL http://www. crisisgroup.org/home/index.cfm? $\mathrm{id}=3342 \& \mathrm{l}=4$

ITTO (2005) Chinese seek certified tropical wood. Tropical Timber Market Report 10(20) (1-15 Dec 2005): 4-5.

Kabemba, C. (2003) Afrique Centrale. In: The Global Corruption Report 2003, ed. Transparency International, pp. 301-307. London, UK: Transparency International.

Karsenty, A. \& Pierre, J.-M. (2005) Les concessions forestières en Afrique centrale-Aspects historiques, institutionnels et politiques du point de vue de la responsabilité sociale et environnementale des entreprises concessionnaires. Étude pour le projet GEPAC de l'Union Européenne, CIRAD, Montpellier, France.

Klare, M.T. (2002) Resource Wars: The Nem Landscape of Global Conflict. New York, USA: Henry Holt and Co.

Kuedisala, F. (2005) Forêt congolaise - des dissensions à la direction exécutive de la Banque mondiale. Le Potentiel (Kinshasa) 20 Décembre 2005 [www document].URL http://fr.allafrica. com/stories/200512200388.html

Labrousse, A. \& Verschave, F.X. (2003) Les Pillards de la forêt. Exploitations criminelles en Afrique. Marseille, France: Agone.

Minnemeyer, S. (2002). An Analysis of Access into Central Africa's Rainforests. Washington DC, USA: Global Forest Watch.
Mittermeier, R.A., Myers, N., Robles-Gil, P. \& Goettsch Mittermeier, C., eds (1999) Hotspots. The Earth's Biologically Richest and Most Endangered Terrestrial Ecoregions. Mexico City, Mexico: Conservation International and CEMEX/Agrupación Sierra Madre.

Muna, A. (2004) The African Union Convention against corruption. In: The Global Corruption Report 2004, ed. Transparency International, pp.109-142. London, UK: Transparency International.

Pearce, D., Putz, F.E. \& Vanclay, J.K. (2003) Sustainable forestry in the tropics: panacea or folly? Forest Ecology and Management 172: 229-247.

Robinson, J.G. \& Bennett, E.L., eds (2000) Hunting for Sustainability in Tropical Forests. New York, USA: Columbia University Press.

Ruiz Pérez, M., Ezzine de Blas, D., Nasi, R., Sayer, J., Sassen, M., Angoué, C., Gami, N., Ndoye, O., Ngono, G., Nguinguiri, J.C., Nzala, D., Toirambe, B. \& Yalibanda, Y. (2005) Logging in the Congo Basin: a multi-country characterization of timber companies. Forest Ecology and Management 214(1-3): 221236.

Sayer, J.A., Ndikumagenge, C., Campbell, B. \& Usongo, L. (2005) Wildlife, loggers and livelihoods in the Congo Basin. In: Forests in Landscapes; Ecosystem Approaches to Sustainability, ed. J.A. Sayer and S. Maginnis, pp. 115-127. London, UK: Earthscan.

Thomson, J. \& Kanaan, R. (2004) Conflict timber: dimensions of the problem in Asia and Africa. Volume 1, Synthesis report. Biodiversity and Sustainable Forestry Indefinite Quantity Contracts (BIOFOR/IQC). USAID, Washington, DC, USA.

USAID (2006) Congo Basin Forest Partnership [www document]. URL http://www.usaid.gov/about_usaid/ presidential_initiative/congobasin.html

Vandenhaute, M. \& Heuse, E. (2006) Aménagement forestier, traçabilité du bois et certification. État des lieux des progrès enregistrés au Cameroun. German Development Cooperation, Yaoundé, Cameroon.

Verbelen, F. (2003) Role of the African Timber Trade in the Creation of Conflict and Poverty - a Call for Action. Amsterdam, the Netherlands: Greenpeace.

WRM (2002) Central Africa: logging one of the world's largest areas of primary rainforest. World Rainforest Movement Bulletin 58: 2-4.

WWF Central African Regional Programme Office (2005) Étude socio-économique et faunique de l'UFA 00-004 de la société TRC. WWF, Yaoundé, Cameroon. 